\title{
EFFECT OF PROPOLIS ON DAMPING- OFF DISEASE OF CUCUMBER IN PROTECTED CULTIVATION \\ EL -KAFRAWY, A. A.
}

Plant Pathology Research Institute, A R C, Giza

(Manuscript received 29 November 2006)

\begin{abstract}
Different concentrations of the proplis ethanol extract (PEE) reduced the radial growth of Fusarium solani, Pythium ultimum and Sclerotinia sclerotiorum and the higher concentration (5000 ppm) was more effective against all the tested fungi . Seedling treatment with the highest concentrations 5 and $4 \mathrm{~g} / \mathrm{l}$ gave the maximum protection and reduced the disease incidence followed by other the treatments. This treatment improved plant height, increased the percentage of flowering, fruit setting and the fruit yield was also increased. The highest concentration $(5 g / l)$, was nearly as effective as the fungicide Topsin $M 70$. The seed treatment with the proplis extract PEE was less effective than seedling treatment in both examined seasons.
\end{abstract}

\section{INTRODUCTION}

Cucumber [Cucumis sativus L.] is one of the most important vegetable crops cultivated under plastic houses in Egypt. It is affected by various plant pathogens causing damping off and root rot which result in great losses in cucumber fruit yield. In the last few years, many efforts were done to reduce the environmental pollution resulting from the application of pesticides.. Propolis is a natural byproduct of honey bees which could be applied safely to the cultivated plants to control phytopathogenic fungi. Bioactivity of propolis against phytopathogenic fungi had been reported by many investigators. Ghisalberti (1979), Peoplinijak et al (1982 ) and La-Torre et $a(1990)$ found that the alcoholic solutions of propolis exhibited fungicidal activity against Botrytis cinerea in vitro and the effect was proportional to the concentration of propolis . In Vivo tests on infected strawberry plants, propolis solution (4000ppm) reduced infection compared with the control. Abdulsalam et al (1995) studied the bioactivity of propolis ethanol extract against ten soil fungi. He indicated that the growth diameter of the tested fungi was decreased significantly with each of the tested propolis extract concentrations. The highest decrease in linear growth was observed in the fungi Fusarium solani, Botrytis sp. and Helminthosporium sp. D'Aulerio et al (1996) observed that the activities of propolis was low against Rhizoctonia solani and Pythium ultimum and F.solani in vitro. Hassanein (1997) found that propolis extract had no antifungal activity against F.moniliforme, Helminthosporium sp, 
Macrophomina phaseolina and R.solani. The aim of the present study was to evaluate effectiveness of propolis on some cucumber damping -off fungi in vitro \& in vivo as well as the growth and fruit yield of treated plants.

\section{MATERIALS AND METHODS}

\section{Effect of propolis on the causal organisms of root-rot disease}

Local prepration of raw materials of propolis was collected from honey bee colonies, Apis mellifera L. in EL. Gharbia Governorate . Collected samples were mixed together and the active ingredients were extracted by ethyl alcohol following the method of Vechet (1978). Propolis ethanol mixture (1:15) was prepared and shaken for 15 hours, with an average of three hours daily during five successive days at room temperature. Then the mixture was filtered and ethanol was evaporated under low pressure at $60^{\circ} \mathrm{C}$. The resulting dry matter was dissolved in $80 \%$ aqueous ethanol to obtain different concentrations. Different dilutions of crude propolis ethanol extract (PEE) were used to evaluate its antifungal activity on Fusarium solani, Pythium ultimum and Sclerotinia sclerotiorum

\section{In Vitro experiments}

Propolis ethanol extract (PEE) was added to hot potato dextrose agar (PDA) to obtain concentrations of $2000,3000,4000,5000 \mathrm{ppm}$. Four plates ( $9 \mathrm{~cm}$ in diameter) from each concentration as well as plain PDA only, as control, were inoculated with fungal discs of F.solani, P.ultimum and S.sclerotiorum and incubated at $28^{\circ} \mathrm{C}$. The radial growth was measured in $\mathrm{cm}$ and the inhibition percentage of the pathogen was calculated .

\section{In Vivo experiments}

Assessment of propolis effect was carried out during 2004-2005 seasons in a greenhouse at Tokh, Kalubia Governorate, which has a disease history of dampingoff and stem rot. Six treatments included the 4 tested proplis treatments( 2,3,4and5 $\mathrm{g} / \mathrm{l})$, the fungicide Topsin $\mathrm{M} 70(3 \mathrm{~g} / \mathrm{l})$ and untreated control were distributed in a completely randomized block design .

\section{Seed and seedling treatment}

Delta Star cucumber cultivar seeds or seedlings were dipped in the 4 concentrations of propolis $(2,3,4$ and $5 \mathrm{~g} / \mathrm{l})$ for 2 hours before sowing or transplanting in the greenhouse. 


\section{The fungicide treatment}

. The cucumber seeds or seedlings were soaked in Topsin M70 praparation at the rate of $3 \mathrm{~g} / \mathrm{l}$. They were sown or transplanted into the soil in rows (each of $7 \mathrm{~m}$ length and $1.5 \mathrm{~m}$ in width) on two ridges. Distance between holes or transplants was $50 \mathrm{~cm}$. Each treatment was replicated in 4 randomized $10.5 \mathrm{~m}^{2}$ plots. Cultural practices were applied as usual. Data were recorded as percentage of disease incidence plant heights and percentage of flowering as well as fruit setting and the yield.

\section{RESULTS AND DISCUSSION}

Data presented in table(1) and figures (1,2 and 3$)$ show the effect of different concentrations of propolis ethanol extracts (PEE) on the radial growth of 'F.solani, P.ultimum and S.sclerotiorum. The data indicate that the radial growth of the tested fungi was greatly decreased by the propolis treatments. The higher concentration of PEE (5000 ppm)was more effective than the lower concentrations against all tested fungi . It inhibited the radial growth of F.solani, P.ultimum and S.sclerotiorum by 88.9, 86.7 and $83.3 \%$ respectively .

Table1. Effect of different concentration of propolis on radial growth (cm) of F.solani, P.ultimum and S.sclerotiorum In Vitro.

\begin{tabular}{|c|c|c|c|c|c|c|}
\hline \multirow{2}{*}{$\begin{array}{c}\text { Concentration of } \\
\text { propolis ppm }\end{array}$} & \multicolumn{2}{|c|}{ F.solani } & \multicolumn{2}{c|}{ P.ultimum } & \multicolumn{2}{c|}{ S.sclerotiorum } \\
\cline { 2 - 7 } & $\begin{array}{c}\text { Radial } \\
\text { growth } \\
(\mathrm{cm})\end{array}$ & $\begin{array}{c}\text { Inhibition } \\
(\%)\end{array}$ & $\begin{array}{c}\text { Radial } \\
\text { growth } \\
(\mathrm{cm})\end{array}$ & $\begin{array}{c}\text { Inhibition } \\
(\%)\end{array}$ & $\begin{array}{c}\text { Radial } \\
\text { growth } \\
(\mathrm{cm})\end{array}$ & $\begin{array}{c}\text { Inhibition } \\
(\%)\end{array}$ \\
\hline 2000 & 4.3 & 52.2 & 5.5 & 38.9 & 4.1 & 54.4 \\
3000 & 3.2 & 64.4 & 4.0 & 55.6 & 3.5 & 61.1 \\
4000 & 1.5 & 83.3 & 2.6 & 71.1 & 2.5 & 72.2 \\
5000 & 1.0 & 88.9 & 1.2 & 86.7 & 1.5 & 83.3 \\
& & & & & & \\
\hline Control & 9.0 & 0.0 & 9.0 & 0.0 & 8.6 & 0.0 \\
\hline & & & & & & \\
\hline
\end{tabular}


The lowest concentration of PEE $(2000 \mathrm{ppm})$ inhibited the radial growth of the tested fungi by $52.2,38.9$ and $54.4 \%$ respectively. The other treatments 3000 and $4000 \mathrm{ppm}$ fall in between. These results are in line with those reported by Abdul salam and Mohamed(1989), who stated that the effective concentrations to inhibit $50 \%$ (IC50) of growth of Fusarium tabacinum, F.heterosporium and F.solani were 250, 320 and $420 \mathrm{ppm}$, respectively. Fungal growth was significantly decreased by each of the tested PEE concentrations with the higher concentration of PEE being more effective than the lower ones against the tested fungi F.solani, Alternaria alternata and Helminthosporium sp. (Abdul salam, 1995).

Data in table (2) show that seed and transplant treatments with the preparations of propolis significantly decreased the percentage of disease incidence on cucumber in the two growing seasons 2004 and 2005 comparing to the untreated control; however, the fungicide Topsin M70 was superior in this respect during the two seasons. The results prove that transplant treatment with propolis generally gave higher protection against cucumber damping off than seed treatment in both seasons at any concentration used. Consequenstly, the percentage of survival plants was increased by increasing the propolis concentration. Concentration of propolis $5 \mathrm{~g} / 1$ gave the lowest percentage of disease incidence $(12.95 \%)$, while $2 \mathrm{~g} / \mathrm{l}$. was less efficient in reducing the disease incidence $(23.15 \%)$ compared with the control (30.92\%). The obtained results in 2004 were more or less similar to those obtained in 2005 . These results are in accordance with those reported by Fahmy \& Omar (1989), who found that soaking onion seeds in 1 and $2.5 \%$ propolis alcoholic extract (PAE) for 4 or $8 \mathrm{~h}$ decreased the percentage of infection or dipping onion seedling for $4 \mathrm{~h}$ in (PAE) minimized the number of sclerotia produced and reduced white rot incidence caused by sclerotium cepivorum under greenhouse condition. La-Torre et al. (1990) found that propolis solution $(4000 \mathrm{ppm})$ reduced infection of strawberry plants by Botrytis cinerea compared with control in vivo. El-Asiuty et al (2000) noted that propolis extract could successfully decrease the incidence of downy mildew on sorghum . 
Table. 2. Effect of propolis concentrations on damping-off incidence of cucumber caused by F.solani, P.ultimum and S.sclerotiorum under greenhouse condition during 2004-2005 seasons.

\begin{tabular}{|c|c|c|c|c|c|c|c|c|}
\hline \multirow{3}{*}{$\begin{array}{c}\text { Propolis } \\
\text { treatmen } \\
\text { ts } g / 1\end{array}$} & \multicolumn{4}{|c|}{ Seed treatment } & \multicolumn{4}{|c|}{ Seedling treatment } \\
\hline & \multicolumn{2}{|c|}{2004} & \multicolumn{2}{|c|}{2005} & \multicolumn{2}{|c|}{2004} & \multicolumn{2}{|c|}{2005} \\
\hline & $\begin{array}{c}\text { Disease } \\
\text { incidence } \\
(\%)\end{array}$ & $\begin{array}{c}\text { Survival } \\
\text { (\%) }\end{array}$ & $\begin{array}{c}\text { Disease } \\
\text { incidence } \\
(\%) \\
\end{array}$ & $\begin{array}{c}\text { Survival } \\
\text { (\%) }\end{array}$ & $\begin{array}{c}\text { Disease } \\
\text { Incidence } \\
(\%)\end{array}$ & $\begin{array}{c}\text { Survival } \\
\text { (\%) }\end{array}$ & $\begin{array}{c}\text { Disease } \\
\text { Incidence } \\
(\%)\end{array}$ & $\begin{array}{c}\text { Survival } \\
(\%)\end{array}$ \\
\hline 2 & 29.02 & 70.98 & 24.94 & 75.06 & 23.15 & 76.85 & 20.35 & 79.65 \\
\hline 3 & 25.24 & 74.76 & 22.18 & 77.82 & 20.85 & 79.15 & 18.94 & 81.06 \\
\hline 4 & 23.93 & 76.07 & 20.79 & 79.21 & 19.98 & 80.02 & 16.64 & 83.36 \\
\hline 5 & 18.65 & 81.35 & 14.53 & 85.47 & 12.95 & 87.05 & 8.88 & 91.12 \\
\hline Topsi M & 12.32 & 87.68 & 9.45 & 90.55 & 7.33 & 92.67 & 6.25 & 93.75 \\
\hline Control & 39.81 & 60.19 & 36.94 & 63.06 & 30.92 & 69.08 & 29.54 & 70.46 \\
\hline $\begin{array}{c}\text { L.S.D. at } \\
5 \%\end{array}$ & 4.89 & 5.12 & 5.94 & 6.14 & ${ }_{6.54}$ & 7.01 & 6.99 & 7.62 \\
\hline
\end{tabular}

Data in table (3)show that seedling treatment with the propolis preporation was more effective in increasing the plant height and yield of cucumber plants more than seed treatment in both two seasons. Data also revealed that treating the seedlings with propolis at 5 and $4 \mathrm{~g} / \mathrm{l}$ were the most effective in improving the plant height from $1.91 \mathrm{~m}$ to 3.42 and $3.21 \mathrm{~m}$, respectively and the yield from 40.14 to 69.95 and $66.45 \mathrm{~kg} / \mathrm{plot}$. respectively. The concentration 3 and $2 \mathrm{~g} / \mathrm{l}$. were the least effective giving plant heights of 3.12 and $3.02 \mathrm{~m}$, respectively, and a yield of 59.74 and $56.98 \mathrm{~kg} / \mathrm{plot}$, respectively. The results obtained were more or less similar in both seasons and are in agreement with those obtained by EL.Assiuty et al (2000) on downy mildew of maize, who noted that propolis extract could significantly increase the grain yield per plant significantly. 
Table 3. Effect of propolis concentrations on plant height and yield of cucumber under greenhouse conditions during 2004,2005 seasons

\begin{tabular}{|c|c|c|c|c|c|c|c|c|}
\hline \multirow{3}{*}{$\begin{array}{c}\text { Propolis } \\
\text { Treatments } \\
g / 1\end{array}$} & \multicolumn{4}{|c|}{ Seed treatment } & \multicolumn{4}{|c|}{ Seedling treatment } \\
\hline & \multicolumn{2}{|c|}{2004} & \multicolumn{2}{|c|}{2005} & \multicolumn{2}{|c|}{2004} & \multicolumn{2}{|c|}{2005} \\
\hline & $\begin{array}{l}\text { Plant } \\
\text { heights } \\
(\mathrm{m})\end{array}$ & $\begin{array}{c}\text { Yield } \\
\text { (kg/plot) }\end{array}$ & $\begin{array}{l}\text { Plant } \\
\text { heights } \\
\text { (m) }\end{array}$ & $\begin{array}{c}\text { Yield } \\
\text { (kg/plot) }\end{array}$ & $\begin{array}{l}\text { Plant } \\
\text { Heights } \\
\text { (m) }\end{array}$ & $\begin{array}{c}\text { Yield } \\
\text { (kg/plot) }\end{array}$ & $\begin{array}{l}\text { Plant } \\
\text { Heights } \\
\text { (m) }\end{array}$ & $\begin{array}{c}\text { Yield } \\
\text { (kg/plot) }\end{array}$ \\
\hline 2 & 2.82 & 49.73 & 2.96 & 51.21 & 3.02 & 56.98 & 3.10 & 60.58 \\
\hline 3 & 2.91 & 50.98 & 3.04 & 54.65 & 3.12 & 59.74 & 3.21 & 62.36 \\
\hline 4 & 3.06 & 54.69 & 3.10 & 60.19 & 3.21 & 66.45 & 3.39 & 68.48 \\
\hline 5 . & 3.12 & 59.93 & 3.19 & 64.28 & 3.42 & 69.95 & 3.54 & 71.89 \\
\hline Topsin M 70 & 2.98 & 58.28 & 3.08 & 62.28 & 3.12 & 68.12 & 3.21 & 69.42 \\
\hline Control & 1.79 & 36.29 & 1.77 & 38.83 & 1.91 & 40.14 & 2.13 & 42.28 \\
\hline L.S.D at $5 \%$ & 0.20 & 5.14 & 0.08 & 5.89 & 0.19 & 7.15 & 0.22 & 5.21 \\
\hline
\end{tabular}

Plot $=1 / 400$ feddan

Data presented in Table (4) indicate that seedling treatment with the propolis extract gave higher percentage of flowering and fruit setting compared with seed. treatment in both season. Treatments of seedling with propolis of concentrations 5 and $4 \mathrm{~g} / \mathrm{l}$ increased the percentage of flowering from 66.14 to 94.92 and $92.45 \%$, respectively, and fruit-setting from $, 61,48$ to 92.86 and $90.14 \%$, respectively in 2004 . Propolis concentrations of 3 and $2 . \mathrm{g} / \mathrm{l}$ gave lower percentage of flowering of 89.64 and $83.45 \%$ and fruit-setting of 86.92 and $80.79 \%$, respectively. This is probably a reflection of the better plant growth parameters as a result of disease control and possible direct effect of metabolites and chemical constituents on the plant. Similar trends were observed in the 2005 experimebts. These results are in accordance with those obtained by EL.Assiuty et $a$. (2000) who found that propolis extract stimulated plant growth of maize. 
The result reported herein indicate the possibility of using proplis preparation to reduce the incidence of damping-off in cucumber caused by different fungi, as a component of an integrated disease control program.

Table 4. Effect of propolis concentrations on flowering and fruit-setting of cucumber under greenhousecondition.

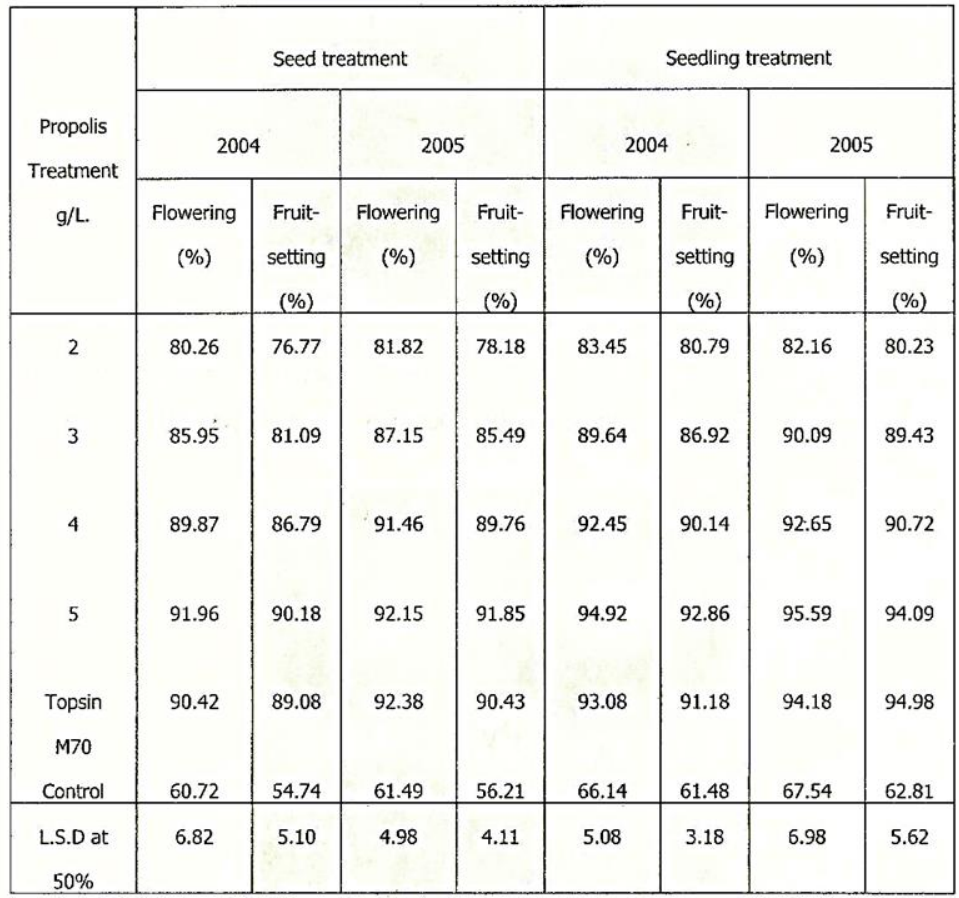




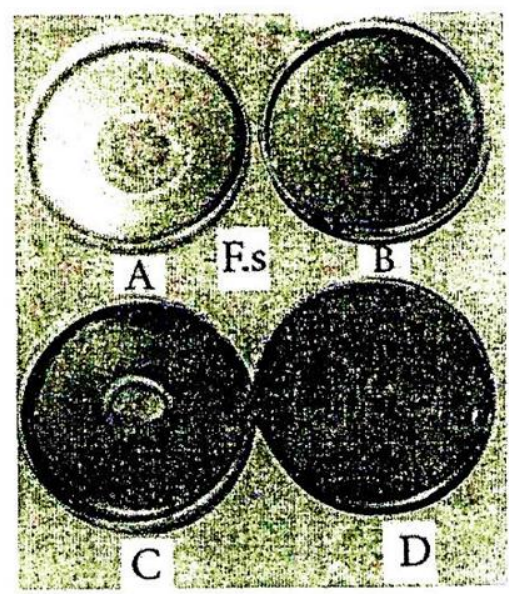

Fig.1. Effect of four concentrations propolis ethanol extract (PEE) against Fusarium soloni( F.S) in vitro. (A) $2000 \mathrm{ppm}$ (B) $3000 \mathrm{ppm}$ (C) $4000 \mathrm{ppm}$ (D) $5000 \mathrm{ppm}$

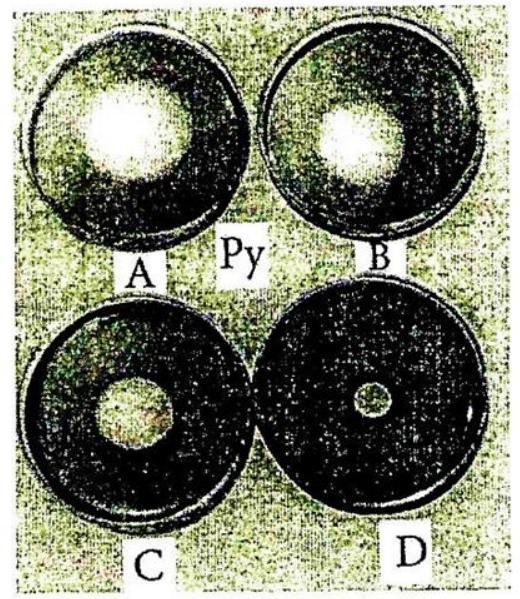

Fig. 2. Effect of four concentrations propolis ethanol extract(PEE)against pythium ultimum (Py) In vitro (A) 2000 ppm (B) 3000 ppm (C) 4000 ppm (D)5000 ppm 


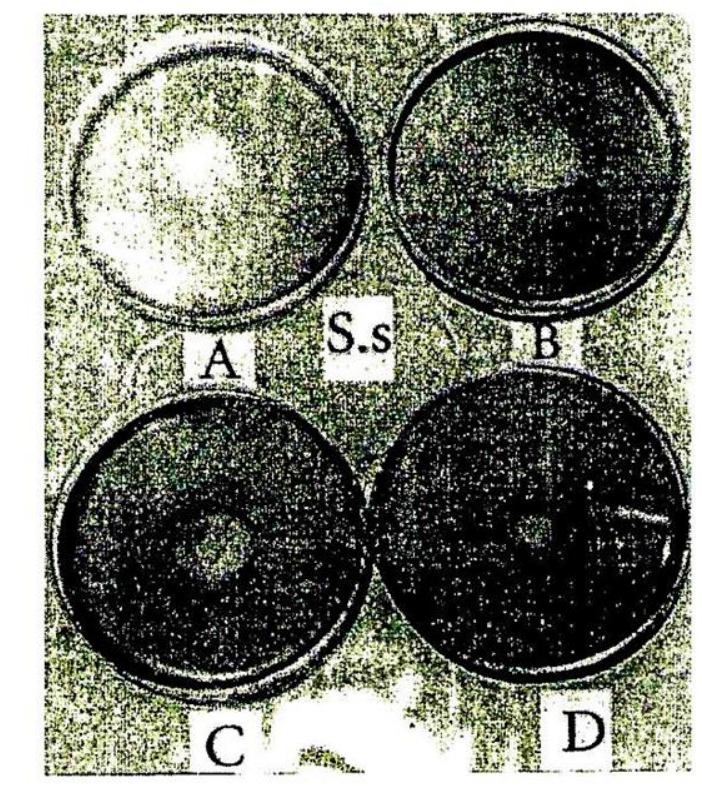

Fig. 3. Effect of four concentrations propolis ethanol extract (pee) against Sclerotinia

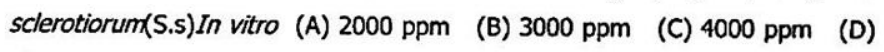
5000ppm 


\section{REFERENCES}

1. Abdul salam, K. S. and M. I Mohamed. 1989. Effect of propolis on some Fusarium spp. Egypt. J. Phytopathol . ,21(2):149-155

2. Abdulsalam, K. S. 1995. Bioactivity of propolis extract against certain soil borne fungi . Alex . J. Agric. Res . 40(3):305-313 .

3. D'Aulerio, A. Z., A. Zambonelli and A. Bianchi. 1996. Natural products in the protection of medicinal plants . Colture-protette . 25(11):99-102

4. EL-Assiuty, E. M. and Zeinab M. Fahmy. 2000. Propolis in controlling sorghum downy mildew and stimulating plant growth of maize. Egypt J. Appl . Sci , 15(12):45-54 .

5. Fahmy, F. G. and M. O. M. Omar. 1989. Potential use of proplis to control white rot disease of onion. Assiut . J. Agric, Sci., 20(1):265-275 .

6. Ghisalberti, E. L. 1979. Propolis . A Review . Bee World , 60(2):59-84

7. Hassanein, F. M. 1997. Evaluation of antimicrobial activity of some bee products against certain phytopathogenic bacteria and fungi . Alex . J. of Agric . Res., 42(3):239-250

8. La-Torre, A., M. Guccinone and G. Imbroglini. 1990. Effect of proplis reparations on Botrytis cinerea on strawberry. Aplicoltura ,(6):169-177 .

9. Peoplinijak, S., D. Maysinger and I. jalsenjak . 1982. Effect of propolis extracts on some fungi . Scientia Pharmaceutic ., 50(2):165 .

10. Vechet, L. 1978. Effect of propolis on some species of microorganisms and moulds . in a remarkable hive product propolis . $535 \mathrm{PP}$, 
تاثير البروبليس على أمراض موت البادرات في الخيارتحت ظروف الصوبه

احمد ابوريا الكفراوى

معهز بحوث أمراض النبات - مركز البحوث الزراعية - الجيزة

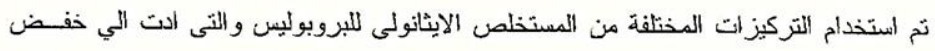

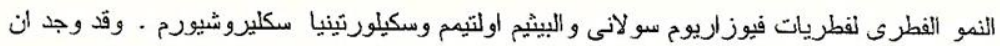

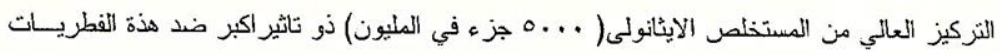

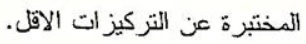

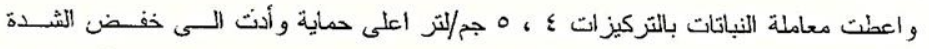

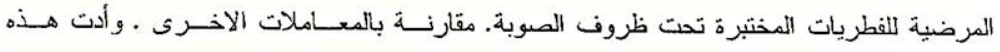

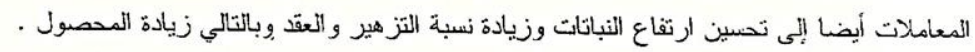

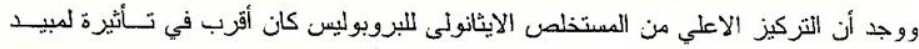

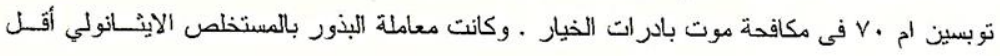

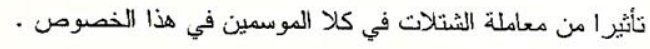

